\title{
RIVER VALLEYS AS ELEMENTS OF THE SYSTEM OF PROTECTED AREAS IN THE LUBLIN ADMINISTRATIVE DISTRICT
}

\author{
WIOLETTA KAŁAMUCKA \\ Department of Environment Protection \\ Maria Curie-Skłodowska University \\ Aleja Kraśnicka 2cd, Lublin \\ e-mail:wkalamuc@poczta.umcs.lublin.pl
}

\begin{abstract}
This article presents results of the research on the protection of the river valleys of Lublin Voivodeship. To determine the degree of protection of the river valleys cartometric methods based on the available maps and the Ministry of Environment and Office of Spatial Planning in Lublin data are used. The results of researches made that the protected landscape areas are element of the system of protected areas, which includes the highest percentage of river length in region (over 13\%). Outside the protected areas, there are $70 \%$ of the length of the river. In this system of protection, fragmentation of the valleys is significant. None of the major rivers of the region, including the Vistula and the Bug, is not protected throughout in their length.
\end{abstract}

Key word: protected area system, river valleys, Lublin Administrative District

\section{INTRODUCTION}

River valley is a term which refers to both a morphological form and-in a broader sense- to the type of the natural environment whose properties are closely connected with the river. The presence of water and the morphology of a valley, which enables erosion, transport and accumulation of material from remote parts of the catchment basin, make river valleys a very important link in the functioning of the natural environment (Olaczek 2000) The interdependence of the individual processes taking place in a valley is even more evident when human impact is added, as river valleys have always been conducive to settlement and land management. Many river valleys, especially those, where the conditions were favourable to the development of agriculture and settlement, and later on-industry, have been considerably transformed (Wojciechowski 2000; German 1998).

The article deals with the protection of river valleys in the Lublin Administrative District. In terms of the diversity of the natural environment it is a very interesting 
area, situated in the contact zone of the European Lowland and the European Upland zones and of Western and Eastern Europe. At the same time, the district lies in the interfluve of the Vistula and the Bug river, whose valleys within the boundaries of the district are representative of the non-regulated large rivers landscape type which is unique by European standards. The Lublin District is also characterised by a great diversity of the river network density and low woodiness, which further increases the role of river valleys in the maintenance of an ecological balance and in the proper functioning of the environment. In order to determine the degree of rivervalley protection, cartometric measurements were carried out based on the available maps, information from the Ministry of the Environment and data provided by the Spatial Planning Office in Lublin, which were examined using computer analysis.

\section{THE STATE OF AREA PROTECTION IN THE LUBLIN ADMINISTRATIVE DISTRICT}

The Lublin Administrative District has a good standing in the statistics of objects and areas of high environmental value. Although its $22.7 \%$ share of areas of special environmental value $\left(5,704.3 \mathrm{~km}^{2}\right)$ gives it the 11 th place in the country $(O c h$ rona Środowiska 2006), when protection forms of a higher rank are taken into account the importance of the Lublin District grows. There are two national parks: the Roztoczański and the Poleski with a total area of 18,245 ha, which places the district in the 6th position in the country. The statistics for landscape parks are even better. The Lublin District boasts the biggest number of landscape parks -16 of them lie mostly or entirely within the administrative boundaries of the district and it comprises a fragment of the Południoworoztoczański Landscape Park (Figure 1). In terms of the area of landscape parks (233,594.2 ha), the Lublin District is second only to the Podkarpackie District, where the number of landscape parks is half as big (7), but owing to the character of the environment it was possible and advisable to create parks over large areas.

The Lublin District also ranks top in the category of ecological farmland, its area amounting to 7,093.5 ha, despite the relatively small number of entities (194). The number of nature reserves places the district in the 10th position, but given their total area of 11,549.5 ha, it is only outstripped by four districts: the WarmińskoMazurski, Podlaski, Mazowiecki and Kujawsko-Pomorski. Habitat refuges and bird sanctuaries in the Natura 2000 network add to the size of the protected area in the district, however it is difficult to specify the quantity as the available materials do not provide data on the size of the area protected by the domestic law.

71 entities in the Lublin District have been included in the Natura 2000 programme. 23 of them are bird sanctuaries of a total area of 324,495.6 ha, and 48-habitat refuges the size of a third of the area-99,504 ha. The area will soon increase as there are plans to create 17 more habitat refuges by 2009 . 


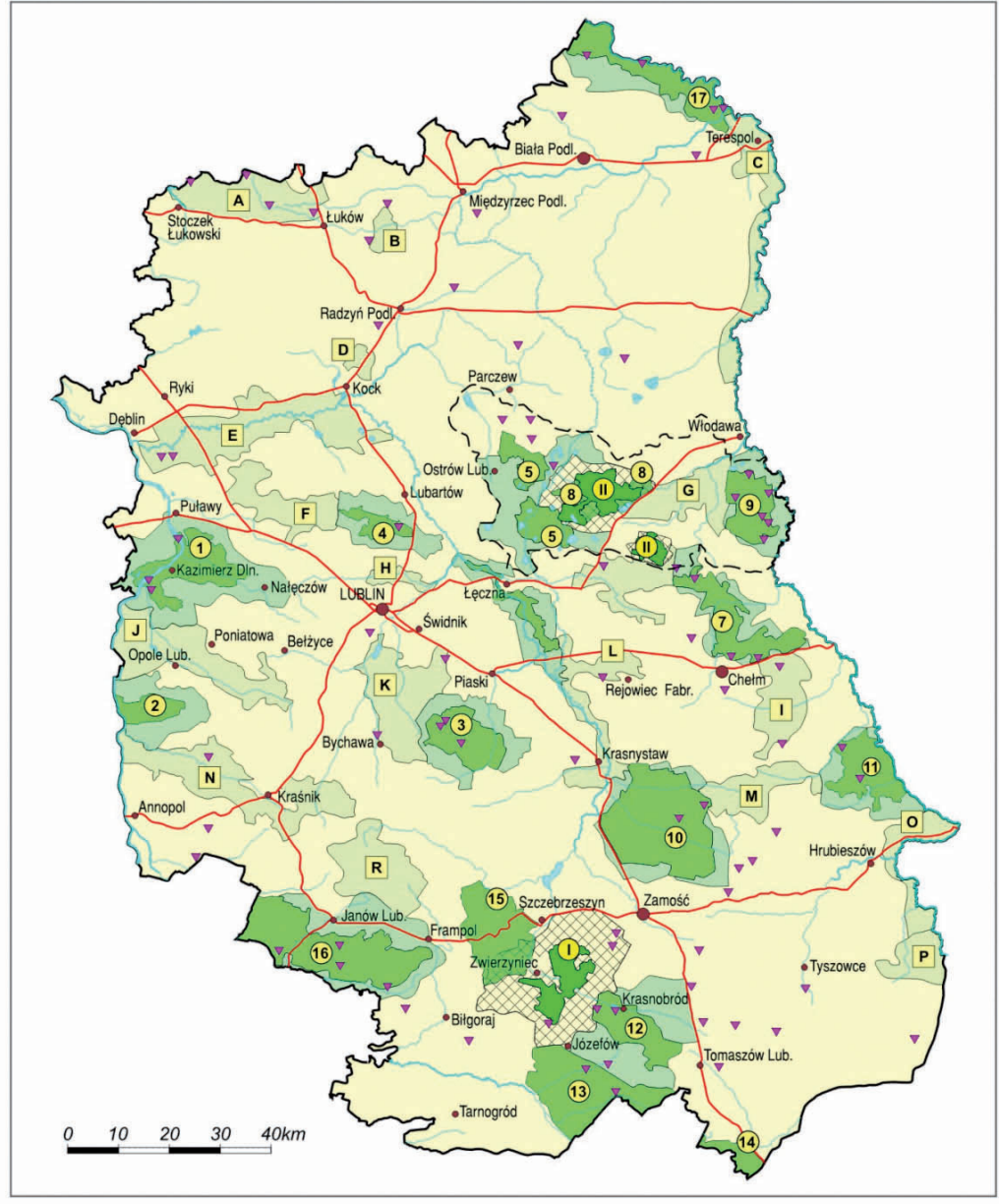

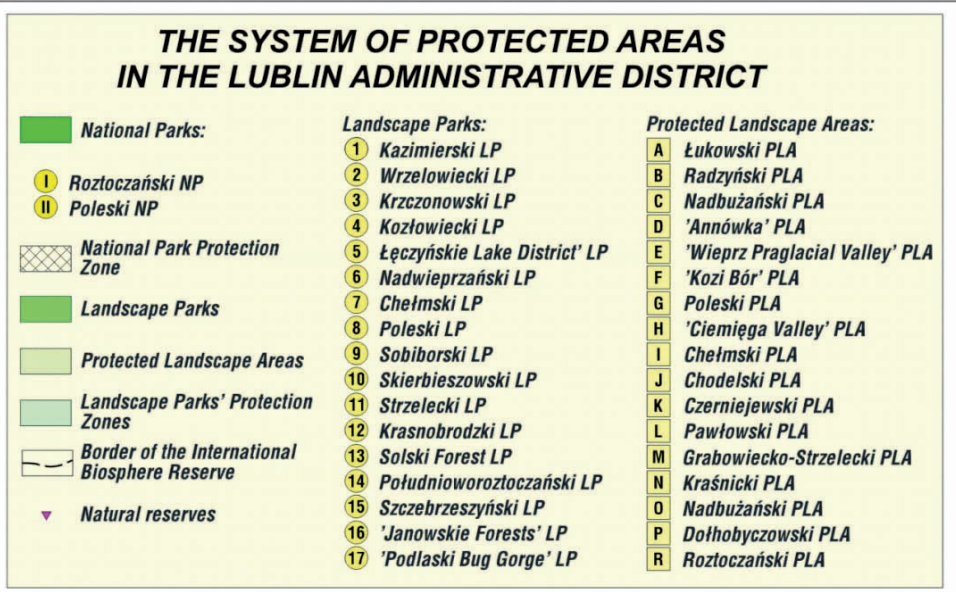

Figure 1. The system of protected areas in the Lublin District Source: Cebrykow and all (2005). 


\section{THE STATE OF RIVER-VALLEY PROTECTION IN POLAND}

The degree of the transformation of river valleys in Poland and in the Lublin Region is much lower than in Western Europe. However, they were neglected in the process of nature protection, which initially focused on forests and mountain areas. Until mid-1970s only fragments of peatbog areas, riverside forests and sites of rare plant species were under protection. According to R. J. Wiśniewski (1998), about 150 rivervalley reserves (apart from those existing within national parks) were established by mid-1990s. They were most often forest reserves (90), landscape reserves (35), faunal (14) and floral reserves (7). Water-head areas were protected in 14 reserves, old river-beds - in 6, and riverside carr-in over 60. In most of the entities, mainly in bird and forests reserves, river valleys were not an object of protection, but merely an element of the environment, essential to the functioning of the reserve. The first reserves which were referred to as river reserves were established in the late $1950 \mathrm{~s}$. They were: the Słonawy Reserve (1957), the Vistula Reserve (1959), the Wełna Reserve (1959). In 1961 the Drwęca Reserve was created, followed by the "Na rzece Grabowej” Reserve as late as 1971 (Wiśniewski 1998).

River-valley conservation has largely been prompted by the Nature Conservation Act from 1991 (Ustawa z dnia 16 kwietnia 1991 r. o ochronie przyrody), which introduced large-space protection forms. Under the Act, many river valleys of high environmental value became protected as part of landscape parks (e.g., Nadnidziański, Popradzki, Drawski, Dolina Słupi) and protected landscape areas (e.g., Nadnotecki, Dolina Narwi, Dolina Rzeki Pasłęki) (Polska. Mapa ochrony... 2001; Polska. Natura... 2004). It should be noticed that river valleys are also protected in the form of national parks. Out of the eight national parks that have been established in Poland since 1990, six comprise vast stretches of water-logged valleys and four: Biebrzański (established in 1993), Drawieński (1990), Narwiański (1996) and Ujście Warty (2001) take their name after a river, which highlights the role that rivers and their valleys play in the functioning of the environment in their area.

The significance of the conservation of river valleys grew after the ratification by Poland of a number of international conventions, such as the Ramsar Convention on Wetlands (1971), the Bonn Convention on the Conservation of Migratory Species of Wild Animals (1979), the Bern Convention on the Conservation of European Wildlife and Natural Habitats (1979) and the Convention on Biological Diversity in 1992 (Weigle 2002). The proposals for valley protection were put forward largely as a result of Poland's participation in the work on the European system of nature protection.

Another important international initiative to protect river valleys took on the shape of the establishment of a European ecological network-ECONETaimed at connecting the networks of protected areas in particular European countries in order to secure a stable and durable functioning of the environment. Ensuring the connections between the environmentally precious areas by means 
of ecological corridors, most of them river valleys, was considered essential for their proper functioning. The concept for a national ecological network ECONET-Poland provided for the protection of $46 \%$ of the area of Poland, including the valleys of all large rivers from springs to river-mouths (Strategia ...1998). However, as the proposal does not have a legal basis, its implementation has been abandoned and efforts have concentrated on the creation of a joint Natura network, as agreed upon in the Treaty of Accession to the European Union. It will be possible to introduce elements of the network into the PEEN network-a European system of interconnected protected areas which is being created on the strength of the Pan-European Biological and Landscape Strategy (1995). The strategy stipulates the tasks which need to be undertaken in order to mitigate the effects of man's activity which results in a degradation of river valleys, water contamination and disturbances in water relations. As part of that initiative, work has begun on a network where large river valleys would be important elements.

The object of the Natura 2000 system is to protect the wildlife habitats which are the most precious in the community. The habitats listed in the annexes to the Habitat Directive and the Birds Directive comprise, among other, muddy riversides, old river-beds, shallow river-mouths, river-side forests, river willow bush and numerous species of plants and animals, especially birds who depend on river valleys for survival.

Due to a limited availability of the data, it is difficult to be precise about the share of river-valley area protected within the various ecological networks. The measurements quoted to illustrate the scope of the phenomenon in the country were based on the available cartographic material—maps at a scale of 1: 75000 , supplemented with the ME materials on the Natura 2000 network to be found on the official website.

Table 1. Percentage of river valleys protected in ESOCH, ECONET-PL network and Natura 2000

\begin{tabular}{|c|c|c|c|c|c|}
\hline & \multirow[b]{2}{*}{$\mathrm{ESOCH}$} & \multirow[b]{2}{*}{ ECONET } & \multicolumn{3}{|c|}{ Natura 2000} \\
\hline & & & $\begin{array}{l}\text { Approved after } \\
\text { consultations } \\
2008\end{array}$ & $\begin{array}{l}\text { Habitat refuges } \\
\text { approved } \\
\text { by } 2004\end{array}$ & $\begin{array}{c}\text { Bird sanctuaries } \\
\text { approved } \\
\text { by } 2004\end{array}$ \\
\hline Vistula & 56.8 & 100 & 18 & - & 57 \\
\hline Odra & 49 & 100 & 16 & 1.5 & 26 \\
\hline Warta & 46.5 & 100 & 3 & 21 & 25 \\
\hline Narew & 74 & 100 & 0 & 39 & 41 \\
\hline Bug & 69 & 90 & - & 39 & 75 \\
\hline
\end{tabular}

Source: own compilation based on cartographic material and MS data as of the end of 2008.

The compilation shows that the valleys of large rivers in Poland would only be entirely protected under the ECONET-PL concept.

The problems of river valley protection were discussed in "The Programme for the protection of river valleys in Poland" (Gacka-Grzesikiewicz and Cichocki 2001)— 
a study prepared by the Institute of Environmental Protection in 1999-2000. The proposal drew on the recommendations of the Water Framework Directive (Directive 2000/60/EC of the European Parliament and of the Council from 23rd October 2000) and the above mentioned Habitat and Bird Directives, as well as on the idea of maintaining the continuity of the protected area of river valleys. 77 valley sections of different length were designated for protection (21 as landscape parks and 56 as areas of protected landscape). The concept was not implemented, but some of the selected areas became protected, mostly in a different shape.

\section{RIVER-VALLEY NETWORK IN THE LUBLIN ADMINISTRATIVE DISTRICT}

The Lublin Administrative District lies at the interfluve of the Bug and the Vistula rivers. The Bug and the Vistula, which forms a picturesque gap in the upland area over a considerable stretch of its course in the district, are boundary river. A right tributary of the Vistula, the Wieprz, is considered the main river in the district, as it is the longest river $(303 \mathrm{~km})$ which is entirely comprised in its borders. The size of its drainage basin surpasses both that of the Bug and its left tributaries and that of the direct catchment basin of the Vistula and its right tributaries, including part of the drainage basin of the San River which occupies the southern part of Roztocze and the Lublin Upland (Table 2).

Table 2. Area of the drainage basins of major rivers in the Lublin Administrative District

\begin{tabular}{|l|c|c|}
\hline \multicolumn{1}{|c|}{ Drainage basin } & $\begin{array}{c}\text { Basin area in the district } \\
\left(\mathrm{km}^{2}\right)\end{array}$ & $\begin{array}{c}\text { Share of the district area } \\
(\%)\end{array}$ \\
\hline $\begin{array}{l}\text { Vistula basin including San } \\
\text { tributaries, without the Wieprz basin }\end{array}$ & 5,735 & 22.9 \\
\hline Wieprz basin & 10,415 & 41.5 \\
\hline Bug basin with its left tributaries & 8,965 & 35.7 \\
\hline
\end{tabular}

Source: Program gospodarki wodnej województwa lubelskiego, (2003), Fundacja Ekspertyz Wodnych, Lublin.

The conditions of water circulation in the described area are varied and have resulted in the formation of a specific pattern of the river network. In the western and central parts of the Lublin Upland and Roztocze the river-valley network is poorly developed. Some areas are counted among the biggest water voids, where the distance from the nearest river or water reservoir is bigger than 5-6 km. The highest density of the river network can be found in the northern part of the district, particularly in Polesie, in two subregions: the Łęczna-Włodawa Lakeland and the Dorohusk Depression. In the drainage basin of the Zielawa, an average medial distance from water-an index used to determine the density of the water network-is as small as $280 \mathrm{~m}$ (Michalczyk and Wilgat 1998). 


\section{WATER OUALITY IN THE RIVERS OF THE DISTRICT}

Water cleanliness in the rivers of the district is assessed by the District Inspectorate of Environmental Protection in Lublin.

Table 3. Water quality in rivers assessed by the District Inspectorate of Environmental Protection in Lublin in 2004-2008

\begin{tabular}{|c|c|c|c|c|c|c|}
\hline & 2004 & 2005 & 2006 & 2007 & $\begin{array}{c}\text { Mean } \\
\text { 2004-2007 }\end{array}$ & 2008 \\
\hline $\begin{array}{l}\text { Length of the studied } \\
\text { rivers }\end{array}$ & 2623 & 2423 & - & - & & \\
\hline $\begin{array}{l}\text { Number of } \\
\text { measurement points }\end{array}$ & 183 & 171 & 180 & 97 & & 114 \\
\hline $\begin{array}{l}\text { Number of studied } \\
\text { rivers }\end{array}$ & 81 & 76 & 71 & 65 & & 72 \\
\hline $\begin{array}{l}\text { Class I-high } \\
\text { quality water }\end{array}$ & - & - & - & - & - & - \\
\hline $\begin{array}{l}\text { Class II-good quality } \\
\text { water }\end{array}$ & 1.7 & 0.6 & - & - & 0.6 & $\begin{array}{l}10.4 \\
\text { (good) }\end{array}$ \\
\hline $\begin{array}{l}\text { Class III—satisfactory } \\
\text { quality water }\end{array}$ & 21 & 21.6 & 16.7 & 7 & 17.6 & $\begin{array}{c}82.6 \\
\text { (moderate) }\end{array}$ \\
\hline $\begin{array}{l}\text { Class IV_-unsatisfactory } \\
\text { quality water }\end{array}$ & 66.3 & 63.7 & 59.4 & 74 & 65.2 & $\begin{array}{c}5.7 \\
\text { (poor) }\end{array}$ \\
\hline $\begin{array}{l}\text { Class } V+\text { poor quality } \\
\text { water }\end{array}$ & 11 & 14.6 & 23.9 & 16 & 16.5 & 1.1 \\
\hline
\end{tabular}

Source: Raport o stanie środowiska województwa lubelskiego (2008, 2009), Inspekcja Ochrony Środowiska, Wojewódzki Inspektorat Ochrony Środowiska, Biblioteka Monitoringu Środowiska, Lublin.

The assessment of water quality in 2008 was carried out by government's order on 13th May 2009 (Dz.U. 2009 nr 81 poz. 685). Given the ongoing process of adapting the evaluation methods for the biological elements of water quality and the pending specification of boundary values for water quality classes, the assessment is of a preliminary nature. The poor condition of water was mostly due to a high content of organic substances and some physical and chemical properties. As the cases of standard exceedance are becoming scarce, it may be argued that the quality of river water is steadily improving. The river waters of the Lublin District do not pose a hazard of contamination with heavy metals.

\section{THE STATE OF RIVER-VALLEY PROTECTION IN THE LUBLIN ADMINISTRATIVE DISTRICT}

Numerous fragments of river valleys have been encompassed by the system of protected areas in the Lublin District. It was possible to determine the degree of pro- 
tection of the monitored medium-sized and large rivers using data obtained from the Spatial Planning Office, which were analysed by computer together with the reports from the District Inspectorate of Environmental Protection, data from the ME and cartographic materials. A compilation of the results of the analysis in terms of river length in the system of protected areas is presented in Table 4.

Table 4. Rivers in the protected area system of the Lublin District

\begin{tabular}{|l|c|c|c|}
\hline \multicolumn{1}{|c|}{ Protection form } & River length in $\mathrm{km}$ & $\begin{array}{c}\text { Mean river length } \\
\mathrm{km} / \mathrm{km}^{2}\end{array}$ & $\begin{array}{c}\text { Proportion of river } \\
\text { length to river length } \\
\text { in the district }\end{array}$ \\
\hline National parks & 55.1 & 3.0 & 0.6 \\
\hline $\begin{array}{l}\text { National park buffer } \\
\text { zones }\end{array}$ & 112.5 & 0.2 & 1.3 \\
\hline Landscape parks & 773.8 & 3.2 & 9.3 \\
\hline $\begin{array}{l}\text { Landscape park } \\
\text { buffer zones }\end{array}$ & 714 & 0.3 & 8.6 \\
\hline $\begin{array}{l}\text { Areas of protected } \\
\text { landscape }\end{array}$ & 1103 & 3.6 & 13.6 \\
\hline Bird sanctuaries & 920.6 & 0.5 & 11.1 \\
\hline Habitat refuges & 141.9 & 0.4 & 1.7 \\
\hline
\end{tabular}

Source: own compilation based on supplemented data from the Spatial Planning Office in Lublin and the ME

It follows from the compilation that areas of protected landscape are the element of the system which comprises the biggest proportion of the river length in the district (over 13\%). The length of river sections in bird sanctuaries is only slightly smaller (11.1\%), while in landscape parks it amounts to $9.3 \%$, yet their buffer zones increase the proportion to nearly $17 \%$. Almost $70 \%$ of river length in the district is beyond the boundaries of protected area. It includes the valleys of the biggest Polish rivers and of small rivers of the 5th or 6th order. In the described system river valleys are rarely protected in their entire stretch. In many cases, valley sections of high environmental value and ecological significance were excluded from protection due to the multi-stage nature of the system creation under changing administrative division and the adoption of different concepts of protection.

It is possible to maintain the ecological cohesion of the system if large areas are accounted for in the preparation of the protected areas network. It is a difficult, but not impossible task, which is proved by the example of the south-western part of the present-day Lublin District. A network of protected areas of the Lublin District in its former boundaries was established there, based on the proposal of a team working under Professor T. Wilgat (1992). In the system, river valleys played a major role as a framework for landscape parks and areas of protected landscape. The protection applied to the entire Vistula Valley gap in the uplands, the whole Wyżnica and Chodelka valleys, the marginal stream valley of the Wieprz River and its gap in 
the vicinity of Łęczna, the upper course of the Giełczew and of its tributaries. In that concept, the valleys of the Wieprz and lower Tyśmienica, Bystrzyca, Ciemięga and Giełczew, which are crucial to the functioning of the natural environment, but lie beyond the boundaries of parks and protected landscape areas, were granted the status of ecological corridors. They were natural connectors between the individual elements of the system which thus merged into a cohesive whole. At that time, such solutions were quite innovative and although the corridors were not given a legal status, their designation was important for subsequent concepts of the spatial management of the district.

High fragmentation of valleys is a noticeable feature of the discussed system. None of the big rivers of the region, including the Vistula and the Bug, is protected in its entire length. The main river in the district-the 303-km-long Wieprz, is protected in varying degree in as many as 16 stretches, of which: $24.6 \mathrm{~km}$ lies in the national park and its buffer zone, $51.5 \mathrm{~km}$-in landscape parks, $32.7 \mathrm{~km}$-in landscape park buffer zones, $104.5 \mathrm{~km}$-within areas of protected landscape. Habitat and bird refuges in the Wieprz Valley contain $23.6 \mathrm{~km}$ of its length. Rivers in the protected areas of Roztocze: the Niepryszka, Sopot, Szum, and in the Lasy Janowskie Landscape Park: the Rakowa and the Branew are protected in their entire stretch.

\section{SUMMARY}

River valleys are some of the most valuable elements of the environment and at the same time they possess conditions favourable to settlement and economic activity. The two functions are frequently in conflict with each other. The awareness of the significance of valleys, particularly as ecological corridors which guarantee the correct functioning of the environment, has led to their inclusion in the system of protected areas. In the Lublin District, which lies at the junction of different geographical and natural regions, the role of river valleys as migration routes is very important. Apart from their ecological function, river valleys, especially in the upland part of the district, have a unique landscape value, both by domestic and European standards, and are becoming recreation and educational sites. The scope of legal protection in the Lublin District does not reflect the role of the valleys in the geographic environment. Many valley sections have been excluded from the protection system, are protected only on one side, or the rank of the area does not ensure them sufficient protection. In order to strengthen the ecological system and for the system to function properly the network of protected areas needs to be supplemented. It is a difficult task to perform presently owing to the fears of the local authorities, who equate the presence of protected areas with limitations to investment.

A comparison of the environmental significance of river valleys with the distribution of the existing protected areas provokes reflection on the imperfection of the available categories of protection. A category, which would aim at protecting the valley in 
particular as a type of the environment is obviously missing. The proposal of recognising river valleys as ecological corridors put forward in various works is not legally valid, which results in investments being realized and a consequent degradation of the environment occurring. Granting ecological corridors the status of environment protection forms would definitely improve the efficiency of the protection of rivervalley environment both in the Lublin District and throughout the country.

\section{REFERENCES}

Cebrykow, P., Grzechnik, L., Kałamucki, K., Krukowski, M. (2005), Województwo lubelskie. Mapa turystyczna, 1: 300 000, Kartpol, Lublin.

Gacka-Grzesikiewicz, E. and Cichocki, Z. (2001), Program ochrony dolin rzecznych $w$ Polsce, Instytut Ochrony Środowiska, Warszawa.

German, K. (1998), Konflikt funkcji przyrodniczych i antropogenicznych w dnach dolin, Materiały archiwalne Biura Planowania Przestrzennego, Lublin.

Michalczyk, Z. and Wilgat T. (1998), Stosunki wodne Lubelszczyzny, Wydawnictwo Uniwersytetu Marii Curie-Skłodowskiej, Lublin.

Ochrona środowiska (2006), GUS, Warszawa.

Olaczek, R. (2000), Antropogeniczne czynniki przeksztatcania dolin rzecznych, in: Kołtuniak, J. (ed.) Rzeki—kultura, cywilizacja, historia, 9, „Śląsk” Spółka z o.o. Wydawnictwo Naukowe, 119-142.

Polska. Mapa ochrony przyrody, 1: 750 000, (2001), PPWK, Warszawa.

Polska. Natura 2000 na tle innych form ochrony przyrody, 1: 750 000, (2004), Ministerstwo Środowiska, PPWK, Warszawa.

Program gospodarki wodnej województwa lubelskiego (2003), Fundacja Ekspertyz Wodnych, Lublin.

Raport o stanie środowiska województwa lubelskiego, (2008, 2009), Inspekcja Ochrony Środowiska, Wojewódzki Inspektorat Ochrony Środowiska, Biblioteka Monitoringu Środowiska, Lublin.

Rezerwaty przyrody w Polsce, (1977), Czubiński, Z., Gawłowska, J., Zabierowski, K., (eds.), Studia Naturae, series B, 27, PWN, Warszawa-Kraków.

Rozporzadzenie Ministra Środowiska z dnia 13 maja 2009 r. w sprawie form $i$ sposobu prowadzenia monitoringu jednolitych czesści wód powierzchniowych i podziemnych (Dz.U. $2009 \mathrm{nr} 81$ poz. 685).

Strategia wdrażania krajowej sieci ekologicznej ECONET-POLSKA (1998), Liro, A. (ed.), IUCN, Warszawa.

Ustawa z dnia 16 kwietnia 1991 r. o ochronie przyrody, (Dz. U. 1991 nr 114, poz. 492).

Weigle, A. (2002), Konferencje i porozumienia przyrodnicze ratyfikowane przez Polskę, IUCN, Warszawa.

Wilgat, T. (ed.), (1992), System obszarów chronionych województwa lubelskiego, UMCS, TWWP, Lubelska Fundacja Ochrony Środowiska, Lublin. 
Wiśniewski, R.J. (1998), Aktualny stan ochrony przyrody rzek i środowisk przyrzecznych, in: Dobrowolski, K.A. and Lewandowski, K. (eds.), Ochrona środowisk wodnych $i$ błotnych, Oficyna Wydawnicza Instytutu Ekologii PAN, Dziekanów Leśny, 72-75.

Wojciechowski, H.K. (2000), Człowiek i rzeka w układzie przyrodniczym i gospodarczym, in: Kołtuniak, T. (ed.) Rzeki-kultura, cywilizacja, historia, tom 9, Katowice, 187-198. 
http://rcin.org.pl 